Jurnal Gizi Klinik Indonesia

Vol. 17 No. 1, Juli 2020 (43-52)

ISSN 1693-900X (Print), ISSN 2502-4140 (Online)

Tersedia online di https://jurnal.ugm.ac.id/jgki

DOI: https://doi.org/10.22146/ijcn.38913

\title{
Kualitas hidup lansia hipertensi dengan overweight dan tidak overweight
}

The quality of life in elderly hypertension with overweight and non-overweight

\author{
Tri Mei Khasana ${ }^{1}$, Nyoman Kertia ${ }^{2}$, Probosuseno ${ }^{2}$
}

'Program Studi Gizi Program Sarjana, Fakultas Ilmu Kesehatan, Universitas Respati Yogyakarta

${ }^{2}$ Departemen Ilmu Penyakit Dalam, Fakultas Kedokteran, Kesehatan Masyarakat, dan Keperawatan, Universitas Gadjah Mada, Yogyakarta

\begin{abstract}
Background: Indonesia will enter the period of aging and an increase in several elderlies with chronic diseases. The biggest health problems of the elderly are degenerative diseases, namely hypertension which significantly disrupts the quality of life both in terms of physical and mental health. One of the causal conditions associated with hypertension is overweight and obesity, which is known at this time the prevalence of obesity is growing progressively in old age. However, the results of research related to the influence of obesity on quality of life are still controversial. Objective: To determine differences in quality of life between hypertensive elderly who are overweight and non-overweight. Method: Cross-sectional study conducted in Yogyakarta City in Januari-April 2017 with a subject of 200 elderly people aged 60-74 years. Overweight was determined based on BMI measurements $\left(>23 \mathrm{~kg} / \mathrm{m}^{2}\right)$ with an estimation of elderly height using depa length, quality of life of the elderly was measured using WHOQOL-BREF questionnaire, and compared the quality of life by age, gender, education, occupation, income, marital status, comorbidity, and disease history. Data analysis used independent t-test and linear regression. Results: Mean of environmental domain score was significantly higher $(p=0,012)$ in elderly hypertension with overweight $(26,69 \pm 3,28)$ compared to elderly hypertension non-overweight $(25,44 \pm 3,58)$. Overweight protective effect on the low quality of life of the environment domain because it is influenced by other factors such as marital status, income, and education. Multivariate analysis shows that income and marital status are external factors that consistently influence the quality of life of the elderly both in total scores and per domain. High-income elderly people with married status have a better quality of life score. Conclusions: The mean score of the environmental domain is higher in elderly hypertension with overweight. Quality of life scores will be better in high income elderly and married.
\end{abstract}

KEYWORDS: elderly; hypertension; overweight; quality of life in

\begin{abstract}
ABSTRAK
Latar belakang: Indonesia akan memasuki periode lansia (ageing) dan peningkatan jumlah lansia dengan penyakit kronis. Masalah kesehatan terbesar lansia adalah penyakit degeneratif yaitu hipertensi yang secara bermakna mengganggu kualitas hidup dari segi kesehatan fisik maupun mental. Salah satu kondisi kausal yang berkaitan dengan hipertensi adalah overweight dan obesitas, yang saat ini prevalensi obesitas tumbuh progresif di usia tua. Namun, hasil penelitian terkait pengaruh obesitas terhadap kualitas hidup masih kontroversi. Tujuan: Penelitian ini bertujuan untuk mengetahui perbedaan kualitas hidup lansia hipertensi antara yang overweight dan tidak overweight. Metode: Penelitian cross-sectional yang dilakukan di Kota Yogyakarta pada bulan Januari-April 2017 dengan subjek 200 lansia berusia 60-74 tahun. Status gizi overweight ditentukan berdasarkan pengukuran indeks massa tubuh (IMT $\left.>23 \mathrm{~kg} / \mathrm{m}^{2}\right)$ dengan estimasi tinggi badan lansia menggunakan panjang depa, kualitas hidup lansia diukur dengan kuesioner WHOQOL-BREF, dan variabel luar yang diteliti yaitu usia, jenis kelamin, pendidikan, pekerjaan, pendapatan, status perkawinan, komorbiditas, dan riwayat penyakit. Analisis data menggunakan independent t-tes dan regresi linier. Hasil: Rerata skor domain lingkungan lebih tinggi secara bermakna $(\mathrm{p}=0,012)$ pada lansia hipertensi dengan overweight $(26,69 \pm 3,28)$ dibandingkan dengan lansia hipertensi tidak overweight $(25,44 \pm 3,58)$. Efek protektif overweight terhadap rendahnya kualitas hidup domain lingkungan dipengaruhi faktor lain seperti status pernikahan, pendapatan, dan pendidikan. Analisis multivariat menunjukkan bahwa pendapatan dan status pernikahan merupakan faktor luar yang secara konsisten berpengaruh pada kualitas hidup lansia baik secara total skor maupun per domain. Lansia dengan pendapatan tinggi dan berstatus menikah memiliki skor kualitas hidup yang lebih baik. Simpulan: Rerata skor domain lingkungan lebih tinggi pada lansia hipertensi dengan overweight. Skor kualitas hidup akan semakin baik pada lansia berpendapatan tinggi dan berstatus menikah.
\end{abstract}

KATA KUNCI: lansia; hipertensi; overweight; kualitas hidup

Korespondensi: Tri Mei Khasana, Program Studi Gizi Program Sarjana, Fakultas Ilmu Kesehatan, Universitas Respati Yogyakarta, Jl. Raya Tajem KM 1,5 Maguwoharjo, Depok, Sleman, Yogyakarta, Indonesia, Telp. 0274-4437888, Fax. 0274-4437999, e-mail: trimeikh@respati.ac.id

Cara sitasi: Khasana TM, Kertia N, Probosuseno. Kualitas hidup lansia hipertensi dengan overweight dan tidak overweight. Jurnal Gizi Klinik Indonesia. 2020;17(1): 43-52. doi: $10.22146 /$ ijcn.38913 


\section{PENDAHULUAN}

Hasil proyeksi penduduk Indonesia 2015-2045 menunjukkan persentase penduduk lanjut usia (lansia) terhadap total penduduk akan meningkat dari sebesar 9,0\% pada tahun 2015 menjadi sekitar 19,7-19,8\% pada 2045 sehingga Indonesia telah memasuki era baru yaitu ageing population. Bahkan, populasi lansia di Indonesia diprediksi meningkat lebih tinggi daripada populasi lansia di dunia setelah tahun $2100(1,2)$. Hal ini terkait dengan peningkatan umur harapan hidup (UHH) yang berkontribusi terhadap peningkatan jumlah lansia. Daerah Istimewa Yogyakarta (DIY) adalah provinsi dengan persentase penduduk lansia tertinggi $(13,04 \%)$ sekaligus provinsi dengan UHH tahun 2019 paling tinggi yaitu pada laki-laki 73,13 tahun dan perempuan 76,76 tahun $(3,4)$. Namun, peningkatan UHH ini belum tentu diikuti dengan peningkatan kesehatan, kemampuan bekerja, dan peningkatan usia pension (5). Sebaliknya, semakin meningkat jumlah lansia dengan penyakit kronis akibat proses penuaan.

Sementara itu, situasi global pada saat ini menunjukkan masalah kesehatan terbesar lansia adalah penyakit degeneratif dan diperkirakan pada tahun 2050 sekitar 75\% lansia penderita penyakit degeneratif tidak dapat beraktivitas (tinggal di rumah) (6). Salah satu penyakit degeneratif terbanyak yang ditemukan pada lansia adalah hipertensi (2). Hipertensi secara bermakna mengganggu kualitas hidup dari segi kesehatan fisik maupun mental. Beberapa hasil penelitian menunjukkan bahwa subjek hipertensi dengan komorbiditas memiliki skor kualitas hidup yang lebih rendah dibandingkan subjek hipertensi tanpa komorbiditas (7-10). Salah satu kondisi kausal yang berkaitan dengan hipertensi adalah kegemukan (overweight) dan obesitas (11).

Beberapa hasil penelitian terkait pengaruh obesitas terhadap kualitas hidup masih kontroversi. Banyak penelitian yang menunjukkan obesitas berhubungan dengan kualitas hidup yang buruk pada orang tua termasuk fungsi fisik terganggu, peningkatan nyeri tubuh, dan vitalitas yang berkurang. Bahkan, obesitas di usia setengah baya telah dikaitkan dengan perkembangan demensia vaskular dan penyakit Alzheimer (5). Namun sebaliknya, penelitian lain menemukan efek mendukung/ menguntungkan/netral yang tidak merugikan dari peningkatan indeks massa tubuh (IMT) pada harapan hidup setelah usia 65 tahun. Penelitian tersebut menyatakan bahwa obesitas berhubungan dengan risiko yang lebih rendah terhadap penurunan kognitif di kalangan usia pertengahan lansia dan lansia (12).

Di Indonesia, sejumlah kecil studi telah meneliti kualitas hidup dan status kesehatan lansia (13-15). Namun, belum pernah dilakukan studi yang mengukur kualitas hidup di antara lansia hipertensi yang overweight dan tidak overweight. Memahami kualitas hidup lansia yang hidup dengan hipertensi dan overweight akan membantu para pembuat kebijakan dan petugas kesehatan untuk merancang dan mengimplementasikan program yang tepat dalam menghadapi transisi penuaan demografi. Dengan demikian, penelitian ini bertujuan untuk mengetahui kualitas hidup pada lansia hipertensi yang overweight dan tidak overweight.

\section{BAHAN DAN METODE}

\section{Desain dan subjek}

Jenis penelitian ini merupakan penelitian analitik dengan rancangan penelitian cross-sectional yang dilaksanakan pada bulan Januari - April 2017 di Kota Yogyakarta. Populasi penelitian adalah seluruh lansia berusia lebih dari 60 tahun di Kota Yogyakarta. Subjek penelitian berdomisili di Kota Yogyakarta yang memenuhi kriteria inklusi dan eksklusi yaitu usia 60 - 74 tahun; menderita hipertensi esensial ( $\geq 140 / 90 \mathrm{mmHg}$ ); memiliki IMT kurang dari $23 \mathrm{~kg} / \mathrm{m}^{2}$ (normal) dan IMT lebih dari atau sama dengan $23 \mathrm{~kg} / \mathrm{m}^{2}$ (overweight); dapat berkomunikasi dengan baik; jenis kelamin laki-laki dan perempuan; serta bersedia mengikuti penelitian (informed consent). Kriteria eksklusi adalah lansia dengan penyakit medis umum yang berat (gagal ginjal, gagal jantung); bed rest; dan mengalami penurunan ingatan (demensia).

Jumlah sampel minimal dihitung berdasarkan rumus perhitungan besar sampel dengan tingkat kepercayaan 95\%; proporsi (P) penelitian sebelumnya $22,0 \%$ (13); dan presisi (d) yang diinginkan yaitu sebesar 0,05 sehingga diperoleh jumlah sampel minimal sebanyak 135 orang ditambah $10 \%$ sehingga jumlah subjek yang dibutuhkan dalam penelitian ini sebesar 148 orang. Pengambilan sampel dilakukan secara multistage random 
sampling yang diperoleh dari posyandu lansia aktif pada lima kecamatan terpilih dari empat belas kecamatan yang ada di Kota Yogyakarta yaitu Kecamatan Wirobrajan, Gondokusuman, Danurejan, Umbulharjo, dan Kotagede. Penentuan lokasi secara simple random sampling kemudian dilanjutkan dengan penentuan jumlah sampel di masing-masing posyandu lansia berdasarkan proporsi dan jumlah sampel yang telah ditentukan sehingga sudah mewakili populasi lansia yang ada di Kota Yogyakarta.

\section{Pengumpulan dan pengukuran data}

Variabel yang diteliti dalam penelitian ini adalah variabel bebas yaitu status gizi overweight dan tidak overweight, sedangkan variabel terikat yaitu kualitas hidup lansia. Variabel luar yaitu usia, jenis kelamin, pendidikan (tinggi jika tamat SMA atau perguruan tinggi), pekerjaan (bekerja dan tidak bekerja), pendapatan (tinggi jika $\geq$ upah minimum regional Kota Yogyakarta tahun 2017 sebesar Rp 1.572.200), status perkawinan (menikah dan tidak menikah/janda/duda), riwayat penyakit, dan komorbiditas. Pengumpulan data dilakukan oleh peneliti yang dibantu oleh 7 orang enumerator yaitu 4 orang lulusan S1 Gizi dan 3 orang lulusan DIII Gizi yang telah mendapatkan penjelasan tentang penelitian dan penggunaan instrumen penelitian.

Hipertensi. Rerata dari tiga kali pengukuran tekanan darah dengan kategori hipertensi jika tekanan darah sistolik lebih dari atau sama dengan $140 \mathrm{mmHg}$ dan atau tekanan darah diastolik lebih dari atau sama dengan $90 \mathrm{mmHg}$ (16). Alat yang digunakan adalah tensimeter digital merk Omron type 7120 untuk mengukur tekanan darah.

Status gizi. Penentuan status gizi overweight berdasarkan pengukuran IMT $\left(\geq 23 \mathrm{~kg} / \mathrm{m}^{2}\right)$ (17) yaitu hasil pembagian berat badan dalam kilogram dengan tinggi badan dalam meter kuadrat $\left(\mathrm{kg} / \mathrm{m}^{2}\right)$. Pengukuran berat badan menggunakan timbangan berat badan digital merk Camry type E9003 dengan ketelitian 0,1 kg dan kapasitas $150 \mathrm{~kg}$. Estimasi tinggi badan lansia menggunakan panjang depa dengan ketelitian $0,1 \mathrm{~cm}$. Semua alat tersebut sudah dilakukan kalibrasi dengan hasil layak.

Kualitas hidup lansia. Pengukuran kualitas hidup lansia menggunakan kuesioner World Heath Organization Quality of Life BREF version (WHOQOL-
BREF). Kualitas hidup lansia berdasarkan instrumen WHOQOL-BREF terdiri dari empat domain yaitu domain fisik, domain psikologis, domain sosial, dan domain lingkungan. Oleh karena tidak terdapat nilai total kualitas hidup secara keseluruhan, maka nilai yang diperoleh dari WHOQOL-BREF berupa nilai pada masingmasing domain. Pengukuran kualitas hidup dengan WHOQOL-BREF terdiri dari 24 facets yang mencakup 4 domain (fisik $=7$ pertanyaan; psikologi $=6$ pertanyaan; sosial $=3$ pertanyaan; lingkungan $=8$ pertanyaan) dan 2 facets dari kualitas hidup secara umum yaitu kualitas hidup secara keseluruhan (overall quality of life) dan kesehatan secara umum (general health). Kuesioner WHOQOL-BREF terdiri dari 26 item pertanyaan yang terdiri dari 23 item favourable dan 3 item unfavourable dengan menggunakan 5 tingkat penilaian (skala likert) yaitu nilai satu sampai dengan lima $(18,19)$. Kuesioner kualitas hidup WHOQL-BREF sudah tersedia dalam bahasa Indonesia dan sudah teruji reabilitas $(0,529)$ dan validitas $(0,614)$ pada lansia di Indonesia. Distribusi dua puluh enam pertanyaan pada WHOQOL-BREF adalah simetris dan hasil penelitian menunjukkan instrumen WHOQOL-BREF valid dan reliabel untuk mengukur kualitas hidup pada lansia (20).

\section{Analisis data}

Analisis data untuk mengetahui apakah ada perbedaan kualitas hidup pada lansia hipertensi yang overweight dan tidak overweight dengan menggunakan independent $t$-tes dan tingkat kemaknaan (p) sebesar 0,05 . Analisis multivariat dilakukan dengan uji regresi linier untuk mengetahui faktor luar yang mempengaruhi kualitas hidup lansia. Analisis data menggunakan program Stata 14.2. Penelitian ini telah memperoleh ethical clearance dari Komisi Etik Fakultas Kedokteran Univesitas Gadjah Mada dengan nomor KE/FK/0080/ $\mathrm{EC} / 2017$.

\section{HASIL}

\section{Karakteristik subjek}

Hasil analisis berdasarkan karakteristik subjek penelitian (Tabel 1) menunjukkan bahwa sebagian besar lansia dalam penelitian ini berjenis kelamin perempuan 
Tabel 1. Karakteristik subjek penelitian

\begin{tabular}{|c|c|c|}
\hline \multirow{2}{*}{ Karakteristik } & \multicolumn{2}{|c|}{ Total $(n=200)$} \\
\hline & $n$ & $\%$ \\
\hline \multicolumn{3}{|l|}{ Umur (tahun) } \\
\hline $60-70$ & 151 & 75,5 \\
\hline $71-74$ & 49 & 24,5 \\
\hline \multicolumn{3}{|l|}{ Jenis kelamin } \\
\hline Laki-laki & 51 & 25,5 \\
\hline Perempuan & 149 & 74,5 \\
\hline \multicolumn{3}{|l|}{ Agama } \\
\hline Islam & 175 & 87,5 \\
\hline Non-Islam & 25 & 12,5 \\
\hline \multicolumn{3}{|l|}{ Suku } \\
\hline Jawa & 197 & 98,5 \\
\hline Non-Jawa & 3 & 1,5 \\
\hline \multicolumn{3}{|l|}{ Pekerjaan } \\
\hline Bekerja & 80 & 40,0 \\
\hline Tidak bekerja & 120 & 60,0 \\
\hline \multicolumn{3}{|l|}{ Pendapatan } \\
\hline Tinggi & 47 & 23,5 \\
\hline Rendah & 153 & 76,5 \\
\hline \multicolumn{3}{|l|}{ Pendidikan } \\
\hline Tinggi & 65 & 32,5 \\
\hline Rendah & 135 & 67,5 \\
\hline \multicolumn{3}{|l|}{ Status pernikahan } \\
\hline Menikah & 108 & 54,0 \\
\hline Tidak menikah & 92 & 46,0 \\
\hline \multicolumn{3}{|l|}{ Tinggal } \\
\hline Pasangan & 29 & 14,5 \\
\hline Keluarga besar & 151 & 75,5 \\
\hline Sendiri & 20 & 10,0 \\
\hline \multicolumn{3}{|l|}{ Riwayat penyakit } \\
\hline Tidak ada & 72 & 36,0 \\
\hline Ada & 128 & 64,0 \\
\hline \multicolumn{3}{|l|}{ Komorbiditas } \\
\hline Tidak ada & 122 & 61,0 \\
\hline Ada & 78 & 39,0 \\
\hline \multicolumn{3}{|l|}{ Hipertensi } \\
\hline Terkendali & 82 & 41,0 \\
\hline Tidak terkendali & 118 & 59,0 \\
\hline \multicolumn{3}{|l|}{ Overweight } \\
\hline Tidak overweight & 75 & 37,5 \\
\hline Overweight & 125 & 62,5 \\
\hline
\end{tabular}

(74,5\%); berusia $60-70$ tahun (75,5\%); beragama Islam $(87,5 \%)$; suku Jawa $(98,5 \%)$; tidak bekerja $(60 \%)$; berpendapatan dan berpendidikan rendah $(76,5 \%$ dan 67,5\%); menikah (54\%); tinggal bersama keluarga besar (75,5\%); memiliki riwayat penyakit (64\%); dan tidak memiliki komorbiditas (61\%). Sementara itu, keadaan
Tabel 2. Perbedaan kualitas hidup pada lansia hipertensi yang overweight dan tidak overweight

\begin{tabular}{lccc}
\hline $\begin{array}{c}\text { Domain } \\
\text { kualitas } \\
\text { hidup }\end{array}$ & $\begin{array}{c}\text { Tidak overweight } \\
\text { (Rerata } \pm \text { SD) }\end{array}$ & $\begin{array}{c}\text { Overweight } \\
\text { (Rerata } \pm \text { SD) }\end{array}$ & p \\
\hline Fisik & $24,27 \pm 3,57$ & $24,00 \pm 3,83$ & 0,636 \\
Psikologis & $20,07 \pm 2,96$ & $20,01 \pm 2,76$ & 0,887 \\
Sosial & $9,08 \pm 1,60$ & $9,30 \pm 1,66$ & 0,349 \\
Lingkungan & $25,44 \pm 3,58$ & $26,69 \pm 3,28$ & $0,012 *$ \\
Total skor & $85,44 \pm 9,67$ & $86,55 \pm 9,22$ & 0,418 \\
\hline
\end{tabular}

*bermakna $(\mathrm{p}<0,05)$ dengan independent $t$-test

hipertensi pada lansia sebagian besar tergolong tidak terkendali (59\% tidak konsumsi obat hipertensi) dan lebih dari separuh lansia memiliki status gizi overweight $(62,5 \%)$. Sebagian lansia dengan hipertensi terkendali memiliki tekanan darah yang tergolong normal $(<120 / 80$ $\mathrm{mmHg}$ ) dan pre-hipertensi (sistolik: 120-139 $\mathrm{mmHg}$ dan diastolik: $80-89 \mathrm{mmHg}$ ) masing-masing sebesar $11 \%$ dan 30\% yang kemungkinan disebabkan oleh konsumsi obat antihipertensi secara rutin. Obat yang paling sering dikonsumsi oleh lansia adalah amlodipin dan simvastatin dengan dosis yang berbeda-beda. Berdasarkan hasil wawancara, riwayat penyakit yang paling sering disebutkan oleh lansia adalah sakit pada persendian, gejala stroke, asam urat, dan kolesterol tinggi. Sementara pada sebagian lansia (39\%) yang memiliki komorbiditas, penyakit yang paling banyak ditemukan adalah diabetes mellitus (35,9\%); hiperkolesterol (29,5\%); asam urat $(26,9 \%)$; dan vertigo $(7,7 \%)$.

\section{Perbedaan rerata skor kualitas hidup lansia}

Hasil analisis dengan independent t-test pada Tabel 2 menunjukkan bahwa hanya rerata skor kualitas hidup domain lingkungan yang menunjukkan perbedaan bermakna $(\mathrm{p}=0,012)$ antara lansia hipertensi yang overweight $(26,69 \pm 3,28)$ dan tidak overweight $(25,44 \pm 3,58)$. Demikian juga dengan rerata skor domain sosial dan skor total kualitas hidup yang tampak lebih tinggi pada lansia hipertensi dengan overweight dibandingkan lansia hipertensi yang tidak overweight $(9,30 \pm 1,66$ vs. $9,08 \pm 1,60$ dan $86,55 \pm 9,22$ vs. $85,44 \pm 9,67)$ meskipun selisih skornya kecil dan secara statistik tidak berbeda bermakna ( $\mathrm{p}=0,349$ dan $\mathrm{p}=0,418$ ). Berdasarkan skor total kualitas hidup (26 pertanyaan) menunjukkan rerata skor sebesar $86,13 \pm 9,38$ dengan skor 
Tabel 3. Perbedaan kualitas hidup pada lansia hipertensi berdasarkan variabel luar

\begin{tabular}{|c|c|c|c|c|c|}
\hline \multirow{2}{*}{$\begin{array}{c}\text { Faktor luar } \\
(\text { Rerata } \pm \text { SD) }\end{array}$} & \multicolumn{5}{|c|}{ Domain kualitas hidup } \\
\hline & Fisik & Psikologis & Sosial & Lingkungan & Total skor \\
\hline \multicolumn{6}{|l|}{ Umur (tahun) } \\
\hline $60-70$ & $24,46 \pm 3,63$ & $20,28 \pm 2,64$ & $9,37 \pm 1,62$ & $26,47 \pm 3,34$ & $87,16 \pm 8,67$ \\
\hline $71-74$ & $23,02 \pm 3,84$ & $19,33 \pm 3,30$ & $8,75 \pm 1,61$ & $25,47 \pm 3,67$ & $82,96 \pm 10,78$ \\
\hline $\mathrm{p}$ & $0,019^{*}$ & $0,039^{*}$ & $0,022 *$ & 0,078 & $0,006^{*}$ \\
\hline \multicolumn{6}{|l|}{ Jenis kelamin } \\
\hline Laki-laki & $23,61 \pm 3,65$ & $20,25 \pm 3,47$ & $9,92 \pm 1,86$ & $26,69 \pm 4,00$ & $87,00 \pm 10,79$ \\
\hline Perempuan & $24,27 \pm 3,75$ & $19,98 \pm 2,59$ & $8,98 \pm 1,48$ & $26,07 \pm 3,22$ & $85,84 \pm 8,87$ \\
\hline $\mathrm{p}$ & 0,271 & 0,551 & $0,000^{*}$ & 0,268 & 0,447 \\
\hline \multicolumn{6}{|l|}{ Pekerjaan } \\
\hline Bekerja & $24,09 \pm 3,67$ & $19,71 \pm 2,62$ & $9,00 \pm 1,65$ & $25,44 \pm 3,11$ & $84,74 \pm 8,54$ \\
\hline Tidak bekerja & $24,12 \pm 3,78$ & $20,27 \pm 2,96$ & $9,37 \pm 1,61$ & $26,75 \pm 3,56$ & $87,07 \pm 9,83$ \\
\hline $\mathrm{p}$ & 0,956 & 0,169 & 0,120 & $0,007^{*}$ & 0,085 \\
\hline \multicolumn{6}{|l|}{ Pendapatan } \\
\hline Tinggi & $24,96 \pm 3,82$ & $21,40 \pm 2,63$ & $10,19 \pm 1,76$ & $28,55 \pm 3,22$ & $91,89 \pm 8,60$ \\
\hline Rendah & $23,84 \pm 3,67$ & $19,63 \pm 2,77$ & $8,92 \pm 1,47$ & $25,51 \pm 3,19$ & $84,37 \pm 8,92$ \\
\hline $\mathrm{p}$ & 0,073 & $0,000^{*}$ & $0,000^{*}$ & $0,000^{*}$ & $0,000^{*}$ \\
\hline \multicolumn{6}{|l|}{ Pendidikan } \\
\hline Tinggi & $24,54 \pm 3,92$ & $21,05 \pm 2,32$ & $10,01 \pm 1,53$ & $28,37 \pm 3,10$ & $90,49 \pm 8,29$ \\
\hline Rendah & $23,89 \pm 3,63$ & $19,57 \pm 2,94$ & $8,84 \pm 1,55$ & $25,19 \pm 3,11$ & $84,04 \pm 9,18$ \\
\hline $\mathrm{p}$ & 0,255 & $0,000^{*}$ & $0,000^{*}$ & $0,000^{*}$ & $0,000^{*}$ \\
\hline \multicolumn{6}{|l|}{ Status pernikahan } \\
\hline Menikah & $24,22 \pm 3,97$ & $20,73 \pm 2,79$ & $9,83 \pm 1,75$ & $27,10 \pm 3,53$ & $88,59 \pm 9,92$ \\
\hline Tidak menikah & $23,97 \pm 3,44$ & $19,25 \pm 2,69$ & $8,50 \pm 1,12$ & $25,19 \pm 3,04$ & $83,25 \pm 7,82$ \\
\hline $\mathrm{p}$ & 0,651 & $0,000^{*}$ & $0,000^{*}$ & $0,000^{*}$ & $0,000^{*}$ \\
\hline \multicolumn{6}{|l|}{ Riwayat penyakit } \\
\hline Tidak ada & $25,22 \pm 3,77$ & $20,43 \pm 2,74$ & $9,40 \pm 1,72$ & $26,09 \pm 3,30$ & $87,90 \pm 9,11$ \\
\hline Ada & $23,48 \pm 3,56$ & $19,83 \pm 2,87$ & $9,12 \pm 1,58$ & $26,29 \pm 3,53$ & $85,14 \pm 9,42$ \\
\hline $\mathrm{p}$ & $0,001^{*}$ & 0,155 & 0,236 & 0,694 & $0,045^{*}$ \\
\hline \multicolumn{6}{|l|}{ Komorbiditas } \\
\hline Tidak ada & $24,85 \pm 3,41$ & $20,20 \pm 2,87$ & $9,30 \pm 1,68$ & $25,97 \pm 3,46$ & $87,01 \pm 9,38$ \\
\hline Ada & $22,94 \pm 3,93$ & $19,82 \pm 2,79$ & $9,09 \pm 1,56$ & $26,63 \pm 3,40$ & $84,77 \pm 9,29$ \\
\hline $\mathrm{p}$ & $0,000^{*}$ & 0,361 & 0,369 & 0,186 & 0,100 \\
\hline
\end{tabular}

*bermakna $(\mathrm{p}<0,05)$ dengan independent $t$-test

maksimal sebesar 130. Hasil ini menunjukkan bahwa rerata skor kualitas hidup lansia hipertensi di Kota Yogyakarta cukup tinggi.

Apabila kualitas hidup dilihat berdasarkan variabel luar (Tabel 3), hasil analisis dengan uji independent t-test menunjukkan bahwa umur ( $\mathrm{p}=0,019)$; riwayat penyakit $(p=0,001)$; dan komorbiditas $(p=0,000)$ adalah variabel luar yang berbeda secara bermakna pada skor domain fisik $(\mathrm{p}<0,05)$. Rerata skor kualitas hidup pada domain fisik lebih tinggi pada lansia dengan umur 60-70 tahun dan tidak memiliki riwayat penyakit maupun komorbiditas. Berbeda dengan domain psikologis, sosial, dan lingkungan yang masing-masing menunjukkan perbedaan bermakna $(\mathrm{p}=0,000)$ pada variabel pendapatan, pendidikan, dan status pernikahan. Namun, pada skor domain psikologis ditemukan juga perbedaan pada variabel umur $(p=0,039)$; domain sosial ditemukan juga perbedaan pada variabel umur $(p=0,022)$ dan jenis kelamin $(p=0,000)$; sedangkan pada skor domain lingkungan ditemukan juga perbedaan pada variabel pekerjaan ( $\mathrm{p}=0,007)$.

Lansia berstatus menikah, berpendapatan tinggi, dan berpendidikan tinggi memiliki rerata skor kualitas hidup domain psikologis, sosial, dan lingkungan yang lebih tinggi secara bermakna dibandingkan lansia yang 
tidak menikah/janda/duda, berpendapatan rendah, dan berpendidikan rendah. Di samping itu, rerata skor kualitas hidup domain psikologis lebih tinggi pada lansia berusia 60-70 tahun; skor domain sosial lebih tinggi pada lansia laki-laki dan berusia 60-70 tahun; serta skor domain lingkungan lebih tinggi pada lansia yang tidak bekerja.

Lebih lanjut, hasil analisis pada skor total kualitas hidup menunjukkan perbedaan skor yang bermakna pada variabel umur $(\mathrm{p}=0,006)$; pendapatan $(\mathrm{p}=0,000)$; pendidikan $(\mathrm{p}=0,000)$; status pernikahan $(\mathrm{p}=0,000)$; dan riwayat penyakit $(\mathrm{p}=0,045)$. Rerata skor total kualitas hidup lebih tinggi pada lansia berusia 60-70 tahun, berpendapatan tinggi, berpendidikan tinggi, menikah, dan tidak memiliki riwayat penyakit.

\section{Faktor luar yang mempengaruhi kualitas hidup lansia}

Uji regresi linier dilakukan untuk menganalisis lebih lanjut faktor luar yang paling dominan berpengaruh terhadap kualitas hidup lansia pada masing-masing domain maupun skor total kualitas hidup. Tabel 4 menunjukkan bahwa variabel yang paling dominan berpengaruh pada skor masing-masing domain maupun skor total kualitas hidup adalah pendapatan.

Umur, pendapatan, dan komorbiditas merupakan faktor luar yang berpengaruh pada kualitas hidup domain fisik dengan arah korelasi yang negatif untuk umur dan komorbiditas. Artinya, skor kualitas hidup domain fisik akan semakin baik pada lansia dengan pendapatan tinggi, berusia 60-70 tahun, dan tidak memiliki komorbiditas. Secara berturut-turut variabel yang berpengaruh pada ketiga domain lainnya yaitu variabel status pernikahan dan pendapatan pada domain psikologis sedangkan status pernikahan, pendidikan, dan pendapatan pada domain sosial dan lingkungan. Pada skor total kualitas hidup, variabel yang berpengaruh adalah umur $(p=0,013)$; pendidikan $(p=0,033)$; status pernikahan $(p=0,023)$; pendapatan $(p=0,003)$; dan komorbiditas $(p=0,011)$.

Hasil yang menarik adalah pendapatan dan status pernikahan merupakan faktor luar yang secara konsisten berpengaruh positif terhadap kualitas hidup lansia secara skor total maupun skor per domain. Hanya domain fisik yang tidak dipengaruhi oleh status pernikahan. Artinya, kualitas hidup lansia secara skor total maupun per domain akan semakin baik jika lansia memiliki pendapatan tinggi. Di samping itu, skor domain psikologis, sosial, lingkungan, dan total kualitas hidup akan semakin baik jika lansia berada dalam status menikah. Nilai $\mathrm{R}^{2}$ paling besar ditemukan pada domain lingkungan yaitu sebesar 0,239. Dengan demikian, variabel pendidikan, pendapatan, dan status pernikahan mampu menerangkan

Tabel 4. Faktor luar yang mempengaruhi kualitas hidup lansia

\begin{tabular}{|c|c|c|c|c|c|}
\hline \multirow{2}{*}{ Faktor luar } & \multicolumn{5}{|c|}{ Domain kualitas hidup } \\
\hline & Fisik & Psikologis & Sosial & Lingkungan & Total skor \\
\hline \multicolumn{6}{|l|}{ Umur } \\
\hline Koefisien korelasi & $-0,19$ & & & & $-0,16$ \\
\hline $\mathrm{p}$ & $0,006^{*}$ & & & & $0,013^{*}$ \\
\hline \multicolumn{6}{|l|}{ Pendidikan } \\
\hline Koefisien korelasi & & & 0,18 & 0,30 & 0,16 \\
\hline $\mathrm{p}$ & & & $0,015^{*}$ & $0,000^{*}$ & $0,033^{*}$ \\
\hline \multicolumn{6}{|l|}{ Status pernikahan } \\
\hline Koefisien korelasi & & 0,20 & 0,31 & 0,14 & 0,16 \\
\hline $\mathrm{p}$ & & $0,004 *$ & $0,000 *$ & $0,038^{*}$ & $0,023^{*}$ \\
\hline \multicolumn{6}{|l|}{ Pendapatan } \\
\hline Koefisien korelasi & 0,14 & 0,21 & 0,15 & 0,18 & 0,22 \\
\hline $\mathrm{p}$ & $0,033^{*}$ & $0,004 *$ & $0,045^{*}$ & $0,013^{*}$ & $0,003^{*}$ \\
\hline \multicolumn{6}{|l|}{ Komorbiditas } \\
\hline Koefisien korelasi & $-0,28$ & & & & $-0,16$ \\
\hline $\mathrm{p}$ & $0,000^{*}$ & & & & $0,011 *$ \\
\hline $\mathrm{R}^{2}$ & 0,120 & 0,107 & 0,237 & 0,239 & 0,222 \\
\hline
\end{tabular}

*bermakna $(\mathrm{p}<0,05)$ dengan uji regresi linier 
atau memprediksi nilai kualitas hidup lansia pada domain lingkungan sebesar $23,9 \%$ dan sebesar $76,1 \%$ dipengaruhi oleh faktor-faktor lain yang tidak diteliti.

\section{BAHASAN}

Berdasarkan skor dari keempat domain kualitas hidup, hanya rerata skor domain lingkungan yang menunjukkan perbedaan bermakna antara lansia yang overweight dan tidak overweight. Rerata skor kualitas hidup domain lingkungan pada lansia hipertensi dengan overweight $(26,69 \pm 3,28)$ lebih tinggi dibandingkan yang tidak overweight $(25,44 \pm 3,58)$. Dengan demikian, hanya satu hipotesis penelitian ini yang terbukti yaitu adanya perbedaan kualitas hidup domain lingkungan pada lansia hipertensi antara yang overweight dan tidak overweight.

Domain lingkungan merupakan dimensi kualitas hidup yang terkait sumber pendapatan/keuangan, rasa aman, kesehatan dan kepedulian sosial, lingkungan rumah/tempat tinggal, kesempatan memperoleh informasi, kegiatan rekreasi, layanan kesehatan, dan transportasi. Lansia pada penelitian ini tinggal di Kota Yogyakarta yang memberikan kemudahan akses informasi, rekreasi, layanan kesehatan, dan transportasi. Selain itu, meskipun sebagian besar lansia pada penelitian ini tidak bekerja, sebagian adalah pensiunan $(44,17 \%)$ sehingga tetap memiliki dana pensiun dan jaminan kesehatan yang cukup. Dengan demikian, lansia dengan overweight pada penelitian ini memiliki kualitas hidup domain lingkungan yang lebih baik karena didukung oleh lingkungan kota dan tempat tinggal yang aman, sehat, kemudahan aksesibilitas serta memiliki sumber dana yang cukup untuk memenuhi kebutuhan sehingga lansia lebih mandiri, bebas, dan tidak tergantung kepada orang lain.

Beberapa penelitian menunjukkan status sosial ekonomi berhubungan dengan kualitas hidup $(10,21,22)$. Pada penelitian ini, perbedaan yang bermakna pada kualitas hidup domain lingkungan disebabkan oleh domain lingkungan yang mungkin merupakan indeks komposit sosio-ekonomi sehingga hasilnya sangat terkait dengan status sosial ekonomi. Hal tersebut dijelaskan pada studi sebelumnya bahwa nilai koefisien korelasi yang tinggi $(\mathrm{r}=0,28)$ ditemukan antara domain lingkungan dengan variabel sosio-ekonomi seperti pendidikan dan tingkat sosial dibandingkan tiga domain lainnya dari WHOQOL-BREF (23).

Lebih lanjut, hasil penelitian ini sejalan dengan hasil penelitian di Turki yang menyimpulkan bahwa memiliki nilai IMT yang lebih tinggi dari nilai normal bisa menjadi faktor protektif dari skor kualitas hidup domain lingkungan yang rendah. Meskipun demikian, hasil penelitian tersebut juga membuktikan bahwa setelah mengendalikan variabel perancu yaitu usia, tingkat pendidikan, dan penyakit komorbiditas, subjek dengan overweight dan obesitas memiliki skor kualitas hidup yang jauh lebih rendah dibandingkan dengan individu dengan berat badan normal pada masing-masing domain, kecuali domain lingkungan (23).

Efek protektif dari overweight dan obesitas pada lansia juga ditemukan pada beberapa hasil penelitian lain yang disebut juga sebagai paradoks obesitas (obesity paradox). Paradoks obesitas mengacu pada peningkatan ketahanan hidup terhadap obesitas dibandingkan dengan non-obesitas pada lansia atau pasien dengan penyakit tertentu karena alasan yang belum pasti. Obesitas menempatkan seseorang pada risiko lebih tinggi pada penyakit tertentu, tetapi dari waktu ke waktu justru memberikan manfaat perlindungan (24). Namun, penelitian terkini menyimpulkan bahwa paradoks obesitas ternyata lebih jelas pada pasien dewasa ( $>18$ tahun) dengan kondisi penyakit kronis (25).

Hasil review mendukung paradoks obesitas dalam penuaan kognitif, yaitu massa tubuh awal yang lebih rendah memprediksi kognitif yang lebih baik, tetapi penurunan massa tubuh yang lebih besar dari waktu ke waktu mempercepat penurunan kognitif lansia (26). Demikian juga hasil studi pada populasi lansia di Korea yang menyatakan peningkatan IMT pada lansia usia 65 tahun atau lebih dikaitkan dengan risiko yang lebih rendah terhadap penurunan kognitif terutama pada wanita. Efek protektif dari IMT tinggi terhadap gangguan kognitif mungkin terkait dengan perubahan komposisi tubuh. Penuaan ditandai dengan hilangnya massa tubuh bebas lemak, tetapi massa tubuh bebas lemak (massa otot dan tulang) yang lebih tinggi terlibat dalam mengurangi risiko kerusakan kognitif pada populasi lansia (12).

Efek protektif juga ditemukan pada penurunan kesehatan mental orang dewasa. Hasil penelitian meta- 
analisis menunjukkan ada pola yang berbeda untuk kualitas hidup fisik dan mental. Kualitas hidup fisik berkurang secara signifikan pada orang dewasa dengan overweight dan obesitas sedangkan kualitas hidup mental hanya berkurang pada individu dengan obesitas tingkat III $\left(\geq 40 \mathrm{~kg} / \mathrm{m}^{2}\right)$. Bahkan, kualitas hidup mental meningkat secara bermakna pada individu overweight jika dibandingkan dengan berat badan normal. Alasan mendasar belum dipahami secara jelas, tetapi hasil penelitian menyebutkan beberapa alasan yaitu kuesioner kualitas hidup mungkin tidak sensitif terhadap jenis gangguan pada kesehatan mental yang berhubungan dengan overweight; beberapa budaya masih menerima overweight sebagai simbol kehidupan bahagia; dan prevalensi overweight yang tinggi mungkin bisa mengubah persepsi bahwa overweight dianggap normal (27). Penelitian lain juga menyebutkan bahwa individu yang kurang gizi (underweight) memiliki kualitas hidup yang buruk dalam domain fisik maupun mental sedangkan individu overweight memiliki fungsi fisik yang buruk tetapi kondisi kesehatan mental yang baik (28).

Penelitian ini hanya menemukan perbedaan bermakna pada skor kualitas hidup domain lingkungan antara lansia yang overweight dan tidak overweight. Hal ini kemungkinan karena domain lingkungan terkait dengan keadaan sosial ekonomi yang pada akhirnya akan berpengaruh terhadap kualitas mental lansia, yang menurut beberapa hasil penelitian di atas, kualitas hidup mental pada overweight lebih baik jika dibandingkan berat badan normal. Sementara skor ketiga domain lain menunjukkan rerata skor yang sama (hanya selisih pada angka desimal saja). Hasil ini didukung oleh hasil penelitian di China bahwa subjek dengan overweight memiliki skor yang sama dengan berat badan normal dalam delapan dimensi kualitas hidup berdasarkan kuesioner SF-36 (25). Hal ini kemungkinan karena keadaan overweight tidak jauh berbeda dengan berat badan normal dan belum cukup bermakna untuk terjadinya penurunan kualitas hidup secara fisik maupun mental jika dibandingkan dengan obesitas. Hasil studi lain menunjukkan skor kualitas hidup yang tidak berbeda secara bermakna jika subjek dengan berat badan normal dibandingkan dengan overweight, tetapi skor kualitas hidup akan berbeda bermakna jika subjek dengan berat badan normal dibandingkan dengan underweight, obesitas tingkat I, dan obesitas tingkat II (25).

Faktor luar yang dianalisis pada penelitian ini yaitu usia, jenis kelamin, pendidikan, pekerjaan, pendapatan, status perkawinan, riwayat penyakit, dan komorbiditas. Analisis multivariat dengan regresi linier menunjukkan hasil yang menarik yaitu pendapatan dan status pernikahan merupakan faktor luar yang secara konsisten berpengaruh positif terhadap kualitas hidup lansia pada skor total maupun per domain. Skor kualitas hidup total maupun skor per domain kualitas hidup akan semakin baik pada lansia dengan pendapatan tinggi dan berstatus menikah. Hal ini terkait dengan rasa aman dan bahagia karena kebutuhan secara materi, psikologis, sosial maupun seksual telah terpenuhi pada lansia berpendapatan tinggi dan berstatus menikah yang pada akhirnya menimbulkan kepuasan terhadap kualitas hidup lansia.

Penelitian mengenai pengaruh IMT terhadap harapan hidup sehat (healthy life expectancy) pada lansia wanita menunjukkan hasil bahwa overweight berhubungan dengan sedikit pengurangan angka kematian pada lansia dengan kesehatan yang buruk (dibandingkan dengan berat badan normal). Namun, di antara lansia yang memiliki kesehatan baik, overweight akan meningkatkan risiko kesehatan yang buruk dan mengakibatkan harapan hidup sehat yang lebih sedikit. Penurunan berat badan pada lansia wanita overweight mungkin bermanfaat dalam meningkatkan harapan hidup sehat. Penelitian tersebut juga menyimpulkan bahwa penting untuk memasuki usia tua dalam keadaan sehat (29). Anjuran untuk lansia agar mempertahankan berat badan yang sehat dan status gizi normal. Di samping itu, perlu meningkatkan promosi kesehatan masyarakat oleh petugas kesehatan dalam mencegah penyakit dan kecacatan pada orang dewasa dan remaja untuk memastikan sebanyak mungkin bisa memasuki usia tua dengan kesehatan dan kualitas hidup yang baik.

\section{SIMPULAN DAN SARAN}

Rerata skor kualitas hidup domain lingkungan lebih tinggi secara bermakna pada lansia hipertensi dengan overweight dibandingkan dengan lansia hipertensi tidak overweight. Efek protektif overweight terhadap kualitas 
hidup domain lingkungan yang rendah karena pengaruh faktor lain seperti status pernikahan, pendapatan, dan pendidikan. Pendapatan dan status pernikahan merupakan faktor luar yang secara konsisten berpengaruh positif terhadap skor total dan skor per domain kualitas hidup lansia. Skor kualitas hidup akan semakin baik pada lansia berpendapatan tinggi dan berstatus menikah. Perlu dikembangkan strategi pencegahan yang efektif dan dapat diimplementasikan dalam pencegahan penyakit pada lansia hipertensi, misalnya tata laksana terkait berat badan yang optimal pada kasus lansia dengan overweight dan obesitas, harapannya supaya lansia dapat menjalani masa tua dengan kesehatan dan kualitas hidup yang baik.

\section{Pernyataan konflik kepentingan}

Penulis menyatakan tidak ada konflik kepentingan dalam penelitian ini.

\section{RUJUKAN}

1. Badan Pusat Statistik (BPS RI). Proyeksi penduduk Indonesia 2015-2045 hasil SUPAS 2015 (edisi revisi). [series online] 2018 [cited 19 Juni 2019]. Available from: URL: https://www.bps.go.id/publication/2018/10/19/78d 24d9020026ad95c6b5965/proyeksi-penduduk-indonesia2015-2045-hasil-supas-2015

2. Kemenkes RI. Situasi lanjut usia (lansia) di Indonesia. [series online] 2016 [cited 8 Oktober 2016]. Available from: URL: https://pusdatin.kemkes.go.id/resources/ download/pusdatin/infodatin/Infodatin-lansia-2016.pdf

3. Kemenkes RI. Riset kesehatan dasar (Riskesdas) tahun 2013. Jakarta: Kemenkes RI; 2013

4. Badan Pusat Statistik (BPS). Indikator strategis menurut provinsi tahun 2019. [series online] 2020 [cited $7 \mathrm{Mei}$ 2019]. Available from: URL: https://www.bps.go.id/ QuickMap?id=0000000000

5. Han TS, Tajar A, Lean ME. Obesity and weight management in the elderly. Br Med Bull. 2011;97:169-

6. Kemenkes RI. Gambaran kesehatan lanjut usia di Indonesia. [series online] 2013 [cited 8 Oktober 2016]. Available from: URL: https://pusdatin.kemkes.go.id/ resources/download/pusdatin/buletin/buletin-lansia.pdf

7. Wang R, Zhao Y, He X, Ma X, Yan X, He J, et al. Impact of hypertension on health-related quality of life in a population-based study in Shanghai, China. Public Health. 2009;123(8):534-9. doi: 10.1016/j.puhe.2009.06.009

8. Sazlina SG, Zaiton A, Nor Afiah MZ, Hayati KS. Predictors of health related quality of life in older people with non- communicable diseases attending three primary care clinics in Malaysia. J Nutr Health Aging. 2012;16(5):498-502. doi: 10.1007/s12603-012-0038-8

9. Baune BT, Aljeesh Y. The association of psychological stress and health related quality of life among patients with stroke and hypertension in Gaza Strip. Ann Gen Psychiatry. 2006;5:6. doi: 10.1186/1744-859X-5-6

10. Soni RK, Porter AC, Lash JP, Unruh ML. Health-related quality of life in hypertension, chronic kidney disease, and coexistent chronic health conditions. Adv Chronic Kidney Dis. 2010;17(4):e17-e26. doi: 10.1053/j.ackd.2010.04.002

11. Zygmuntowicz M, Owczarek A, Elibol A, Chudek J. Comorbidities and the quality of life in hypertensive patients. Pol Arch Med Wewn. 2012;122(7-8):333-40.

12. Kim S, Kim Y, Park SM. Body mass index and decline of cognitive function. PLoS One. 2016;11(2):e0148908. doi: 10.1371/journal.pone. 0148908

13. Nawi Ng, Hakimi M, Byass P, Wilopo SA, Wall S. Health and quality of life among older rural people in Purworejo District, Indonesia. Glo Health Action. 2010;3:78-87. doi: 10.3402/gha.v3i0.2125

14. Kamso S. Body mass index, total cholesterol, and ratio total to HDL cholesterol were determinants of metabolic syndrome in the Indonesian elderly. Med J Indones. 2007;16(3):195-200. doi: 10.13181/mji.v16i3.276

15. Kamso S, Rumawas JS, Lukito W, Purwantyastuti. Determinants of blood pressure among Indonesian elderly individuals who are of normal and over-weight: a cross sectional study in an urban population. Asia Pac J Clin Nutr. 2007;16(3):546-53.

16. National Heart, Lung, and Blood Institute (US). JNC VII: The Seventh Report of the Joint Committee on Prevention, Detection, Evaluation, and Treatment of High Blood Pressure. [series online] 2004 [cited 8 Oktober 2016]. Available from: URL: https://www.nhlbi.nih.gov/files/ docs/guidelines/jnc7full.pdf

17. Mann J, Truswell SA. Essentials of human nutrition, fourth edition. (Alih Bahasa: Andry Hartono). Jakarta: EGC; 2014.

18. World Health Organization (WHO). WHO Quality of life BREF (WHOQOL-BREF). [series online] 2009 [cited 8 Oktober 2016]. Available from: URL: https://www.who. int/mental_health/media/en/76.pdf

19. World Health Organization (WHO). Programme on mental health: WHOQOL user manual. [series online] 2012 [cited 8 Oktober 2016]. Available from: URL: https://apps.who. int/iris/handle/10665/77932

20. Salim OC, Sudharma NI, Kusumaratna RK, Hidayat A. Validitas dan reliabilitas World Health Organization Quality of Life-BREF untuk mengukur kualitas hidup lanjut usia. Universa Medicina. 2007;26(1):27-38. 
21. Nilsson E. Aspects of health-related quality of life. Associations with psychosocial and biological factors, and use as patient-reported outcome in routine health care [Dissertations]. Sweden: Linköping University; 2012.

22. Minh HV, Ng N, Byass P, Wall S. Patterns of subjective quality of life among older adults in rural Vietnam and Indonesia. Geriatr Gerontol Int. 2012;12(3):397-404. doi: 10.1111/j.1447-0594.2011.00777.x

23. Dinç G, Eser E, Saatli GL, Cihan UA, Oral A, Ozcan C, et al. The relationship between obesity and health related quality of life of women in a Turkish city with a high prevalence of obesity. Asia Pac J Clin Nutr. 2006;15(4):508-15.

24. Casas-Vara A, Santolaria F, Fernández-Bereciartúa A, González-Reimers E, García-Ochoa A, Martínez-Riera A. The obesity paradox in elderly patients with heart failure: analysis of nutritional status. Nutrition. 2012;28(6):616-22. doi: 10.1016/j.nut.2011.10.006

25. Zhu Y, Wang Q, Pang G, Lin L, Origasa H, Shi H, et al. Association between body mass index and health- related quality of life: the "obesity paradox" in 21,218 adults of the Chinese general population. PLoS One. 2015;10(6):e0130613. doi: 10.1371/journal.pone.0130613

26. Memel M, Bourassa K, Woolverton C, Sbarra DA. Body mass and physical activity uniquely predict change in cognition for aging adults. Ann Behav Med. 2016;50(3):397-408. doi: 10.1007/s12160-015-9768-2

27. Ul-Haq Z, Mackay DF, Fenwick E, Pell JP. Meta-analysis of the association between body mass index and healthrelated quality of life among adults, assessed by the SF-36. Obesity (Silver Spring). 2013;21(3):E322-7. doi: 10.1002/ oby.20107

28. Zhu YB, Luo XX, Wang Q. Study on the relationship between body mass index and health-related quality of life in middle-aged or older Chinese adults. Zhonghua Liu Xing Bing Xue Za Zhi. 2009;30(7):687-91.

29. Leigh L, Byles JE, Jagger C. BMI and healthy life expectancy in old and very old women. Br J Nutr. 2016;116(4):692-9. doi: 10.1017/S0007114516002403 